\title{
Ajustes difíceis
}

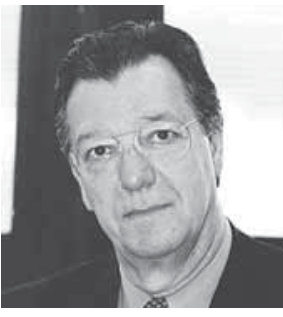

Carlos Osmar Bertero

FGVEAESP
A administração tem paixão por sucessos e fobia por fracassos. A conseqüência disso é que freqüentemente as empresas são privadas das importantes lições que 0 fracasso pode oferecer. Ajustamentos são sempre difíceis, mesmo que sejam feitos para adaptar a organização a condições melhores. Algumas conseguem ajustar-se, mudando estruturas, processos, admitindo e demitindo pessoas.

No entanto, em casos problemáticos, quando é necessário adotar medidas drásticas para a redução de despesas, que implicam revisões de estruturas organizacionais e dispensa de pessoal, o número de empresas que não conseguem seajustar é muito maior. E o resultado extremo, e doloroso para todos, é a falência.

As razões para as dificuldades de ajustamento são as mais diversas. A mais comum é quando há impasse político, ou seja, quando os atores detêm poderes semelhantes e divergem sobre as medidas a adotar. 0 problema é que 0 ajuste implica uma centralização decisória; dificilmente ele é obtido mediante procedimentos consultivos e participativos. Isso leva a que muitas empresas, tendo que realizar ajustes pesados, acabem contratando um consultor externo que deverá fazer 0 turnaround

A consultoria de turnaround trabal ha com o pressuposto de que medidas difíceis têm que ser tomadas de maneira centralizada, às vezes adotando procedimentos arbitrários e sem possibilidade de que as diversas partes atingidas possam recorrer das decisões tomadas. 0 turnaround gera benefícios sob a forma de melhoria da liquidez e da saúde financeira imediata. Mas deixa marcas profundas no clima organizacional e nas pessoas.

Mesmo reconhecendo que ajustes são sempre difíceis e que o caminho está cheio de obstáculos, o que se pode fazer para torná-lo menos sofrido? Primeiramente, a existência de uma boa liderança. Isso significa liderança legítima, ou seja, aceita pela maioria e que esteja disposta a arcar com os ônus, queimando capital político para realizar as mudanças. Em segundo lugar, elas devem ser rápidas. Climas de insegurança geram ruídos, fofocas e boatos em grande quantidade. 0 remédio é manter as linhas de comunicação abertas e informar de maneira clara o que se quer fazer. Nada mais propenso a gerar boatos do que comunicações truncadas ou mesmo falta de comunicação. Ainda que essas medidas sejam adotadas, elas não apagam o fato de que mudar não é fácil. 0 ser humano tem propensão a ser conservador, mantendo-se sempre na sua zona de conforto. Mesmo mudar para melhor gera insegurança e pode levar a que se vacile. Para o que é desconfortável só resta a alternativa de ingerir rapidamente 0 amargo cálice e enfrentar os dissabores. Certamente sempre se espera que depois disso as coisas melhorem. 